\title{
Clay mineralogy and implication for palaeoenvironment of Patala Formation in Salt Range, Lesser Himalayas, Pakistan
}

\author{
Shahina Tariq †* and SRH Baqrił \\ † Institute Earth and Envirnomental Science, Bahria University, Islamabad, PAKISTAN \\ $¥$ Pakistan Museum of Natural History, Islamabad, PAKISTAN \\ *To whom correspondence should be addressed.E-mail:Shahinatariq@yahoo.com
}

In Potwar basin the shaly part of the Patala Formation of Paleocene age stretches from the Salt Range in the southeast to Kala-Chitta Range in northwest. The paleoenvironment of the Potwar basin is interpreted by the diagenetic and sedimentational control of clay minerals in the basin. The clay mineralogy displays kaolonite, illite, with minor mixed layer of illite/ montmorillinte clay minerals and occasional chrlorite. It is inferred that the kaolinite/illite and chlorite minerals are the detrital clay minerals, brought into the depositional basin due to erosion of the source rocks exposed in the southeast of partly diagenetic origin. The clay mineral compositions from the southeast to northwest show that kaolinite decreases while illite and chlorite increase. The decrease of kaolinite in Kala-Chitta Range is most likely due to sedimental/depositional control. The course-grained kaolinite was abundantly deposited in fresh to brackish water conditions in shallow parts of the basin while the conditions changed towards northwest from shallow marine to brackish causing less transportation into deeper parts of the basin. The fine grained illite and chlorite mineral were transported and deposited in abundance in the deeper parts of the basin. No significant variation is observed in mixed-layer clay mineral. The crystallinity indices of kaolinite and illite show an increase in Salt Range where as they decrease in Kala-Chitta Range. The decrease in crystallinity of clay mineral in conjunction with kaolinite deposition patterns, prove the transportation, and deepening of the depositional basin from southeast to northwest. 